DOI 10.37882/2223-2974.2021.01.12

\title{
К ВОПРОСУ О СОЦИАЛЬНОЙ ПОЛИТИКИ РОССИЙСКОЙ ФЕДЕРАЦИИ В ОБЛАСТИ МАТЕРИНСТВА, ОТЦОВСТВА И ДЕТСТВА
}

\section{ON THE ISSUE OF SOCIAL POLICY OF THE RUSSIAN FEDERATION IN THE FIELD OF MOTHERHOOD, FATHERHOOD AND CHILDHOOD}

\section{N. Kuznetsova T. Matveeva}

Summary: The article reveals the importance of the family institution in modern society. Analyzed legislative actions of the state in social policy on protection of family, motherhood, fatherhood and childhood. The analysis of social support of families in the period of coronavirus infection is carried out, and also own ways of improvement of policy of our state in the analyzed sphere are offered.

Keywords: welfare state, legal policy, social protection, social policy, protection of motherhood, fatherhood and childhood, children, woman, motherhood and childhood, the welfare state, maternity, childhood protection.
$\mathrm{B}$ настоящий момент семья выступает полноценной ячейкой общества, является малым социальным институтом любого цивилизованного государства, в связи с чем поддержка семейных ценностей, интересов семьи, детства и материнства является основным приоритетом государственной социальной политики в сфере защиты и поддержки указанных институтов гражданского общества. Роль семьи трудно сегодня переоценить, так как именно семья выступает тем социальным институтом в контексте семейной политики государства, который выполняет функцию самосохранения общества, а также воспроизводства поколений. Семья играет большое значение в жизни каждого человека и общества в целом, семья-это основная ячейка общества и в ней закладывается фундамент будущего гражданина страны. Благополучие семьи во многом зависит от экономической ситуации в стране и именно семья лежит в основе здорового общества. А большая роль в семье отводиться женщине - матери, жене. Но не стоит забывать и об отце. Ведь Семейный кодекс (ст.63) закрепляет равные права родителей по воспитанию и образованию детей. [2] В качестве приоритетных направлений государства выступает поддержка и развитие благополучной семьи, материнства, отцовства и детства. Но в современных условиях семье приходится порой выживать и это отражается на семейном благополучии.

\author{
Кузнецова Наталья Александровна \\ старший преподаватель, ФКОУ ВО «Владимирский \\ юридический институт ФСИН России» \\ kuz1503@yandex.ru \\ Матвеева Тамара Павловна \\ старший преподаватель, ФКОУ ВО «Владимирский \\ юридический институт ФСИН России» \\ matveeva33@mail.ru
}

Аннотация: В статье раскрывается значимость института семьи в современном обществе. Анализируются законодательные действия государства в области социальной политики по охране и защите семьи, материнства, отцовства и детства. Проводится анализ социальной поддержки семей в период коронавирусной инфекции, а также предлагаются собственные пути совершенствования политики нашего государства в анализируемой сфере.

Ключевые слова: социальное государство, правовая политика, социальная защита, социальная политика, защита материнства, отцовства и детства, дети, женщина, охрана материнства и детства, социальное государство, материнство, детство, защита.

По данным Федеральной службы государственной статистики в 2019 году число разводов по отношению к заключаемым бракам составило 65\%.

Если провести сравнение, то картина такова: 30 лет назад такое соотношение определялось 42\%, а 70 лет назад - всего лишь 4\%. Это показывает стабильность брачных отношений в предыдущие годы. Следует все же отметить, что число разводов в 2020 году сократилось, но молодежь не очень стремиться обзаводиться семьей. Принципы семейных отношений уходят на второй план. Быть свободным, не обременяя себя заботой о детях это действительность настоящего времени. [5]

Именно поэтому в Российской Федерации сегодня особое внимание уделяется охране материнства и детства, поддержке женщин, детей и многодетных семей. Полагаем верным направлением социальной политики в Российской Федерации, когда особое внимание будет уделяться тому, чтобы каждая женщина имела необходимые условия для рождения ребенка, чувствуя защиту и поддержку государства. На национальном уровне это должно решить проблему обеспечения воспроизводства населения, то есть ситуацию, когда рождаемость превышает смертность, половина семей должно иметь двоих детей, а половина троих, т.е. быть многодетными. 
Реализуя меры социальной семейной политики, государство придерживается направления социального партнерства с помощью различных организационноуправленческих структур, учитывая при этом интересы и потребности отдельно взятой семьи, а также возможностей экономики государства. Ни для кого не секрет, что охрана и защита каждого отдельно взятого ребенка является непосредственной обязанностью как государства и общества в целом, так и каждого индивида в отдельности.

Однако, даже несмотря на важность и значимость анализируемого вопроса, нормативно-правовое регулирование защиты и охраны семьи, материнства, отцовства и детства, на сегодняшний день находится на недостаточном уровне и далеко от совершенства.

Например, в своем выступлении 17 декабря 2020 года Президент Российской Федерации Владимир Путин отметил, что ввиду отмены новогодних мероприятий семьям где есть дети до 7 лет будет выплачено по 5 тысяч рублей. [6] Да, это хороший подарок детям, но возникает вопрос почему именно детям до 7 лет. Ведь и в 8 лет, и в 9, и в 10 лет и даже в 15 лет дети ждут праздников. Чем руководствовалось наше государство выделяя именно детей до 7 лет?

Напомним, что дети с рождения до 3 лет это самая обеспечиваемая государством детская социальная группа, целесообразнее было сместить меры поддержки в сторону целевой группы 3-10 лет.

Но все же стоит отметить, что сфера охраны семьи, материнства, отцовства и детства - это созданная и охраняемая государством область общей государственной социальной политики, непосредственной задачей которой выступает создание и обеспечение семей, детей и женщин условиями, которые положительным образом будут служить для создания, развития и воспроизводства семьи в нашем обществе, а также для осуществления ее непосредственных функций.

С 2015 года начал свою работу Евразийский женский форум - крупнейшая международная площадка, посвященная роли женщины в современном обществе. Второй Евразийский женский форум «Здоровье женщин-благополучие нации» состоялся в сентябре 2018г. в Санкт-Петербурге. Он был организован Советом Федерации РФ совместно с Минпромторгом РФ и Фондом Инносоциум - социальной платформой Фонда Росконгресс при поддержке Минздрава РФ. Целью проведения форума было повысить роль женщины в современном мире, создать условия для создания и продвижения программ и проектов в рамках международного сотрудничества как внутри страны, так и за ее пределами.
Значимую работу форума в развитии и продвижении актуальных социальных программ, социальной интеграции общества, в решении не только внутригосударственных, но и международных вопросов отмечал также Президент Владимир Владимирович Путин. Он подчеркнул важность форума в выработке эффективного механизма многостороннего сотрудничества, роли женщин по повышению качества и продолжительности жизни, улучшении демографической ситуации в стране. Форум вносит большой вклад по совершенствованию законодательства и расширению правовых, экономических, социальных возможностей женщин.

Президент РФ неоднократно в своих выступлениях обращает внимание, что поддержка материнства и детства - это безусловный государственный приоритет и важная общенациональная задача на сегодняшний день.

Его слова о поистине уникальном вкладе женщин в решение многих первоочередных задач государства неоспоримы. Сегодня женщины успешно трудятся в образовании и системе здравоохранения, в социальной сфере и органах власти, в бизнес-структурах и общественных организациях. [3] Кроме того, женщины деятельно участвуют в реализации востребованных проектов, которые направлены на продвижение ценностей многодетной семьи, здорового и активного образа жизни, на воспитание подрастающих поколений, профилактику молодежной и детской преступности.

Семья - это основа любого государства. Крепкая, счастливая семья - залог того, что дети вырастут здоровыми, всесторонне развитыми и полноценными гражданами своей страны. Как справедливо полагает Д. Левицкий, государственная политика предполагает сохранение традиционных семейных ценностей и повышение роли семьи в жизни общества. [4]

Действительно, безопасность детей, защита интересов семей, материнства, отцовства и детства - это фундаментальные проблемы для любого общества, а тем более для нашей страны. На сегодняшний день в нашей стране принят ряд мероприятий, которые решают комплексные вопросы обеспечения комфортной среды для семей, в частности:

- федеральные и региональные программы обеспечения нуждающихся семей жильем, льготная ипотека для семей с младенцами, субсидируемая государством;

- материальное стимулирования рождаемости, путем введения программы материнского капитала, социальных выплат и льгот;

- поддержка семей, оказавшихся в сложных жизненных обстоятельствах, например, пандемии коронавируса, стимулирование занятости;

- создание образовательных интернет-ресурсов, 
региональных систем дополнительного образования и др.

B период кризиса, обусловленного пандемией COVID-19, властями инициированы прямые денежные выплаты в целях поддержки семей, в которых имеются несовершеннолетние дети. Причем данные выплаты имеют возрастную градацию и были направлены на поддержание российских семей, а большая часть из них стала ежемесячной поддержкой семьям в трудной для них ситуации, когда большая часть населения просто остались без работы, и, соответственно, и без средств к существованию. Данная помощь от государства считается беспрецедентным случаем поддержки государства в условиях всеобщей пандемии.

Попробуем разобраться что же было сделано в 2020 году в качестве поддержки:

- единовременная выплата 10000 рублей на каждого ребенка в возрасте от 3 до 16 лет. Эта компенсационная выплата на детей в связи с коронавирусом предназначена всем семьям, имеющим детей, родившихся в период с 11.05.2004 по 30.06.2017 и являющихся гражданами РФ. Выплату может получить один из родителей, единственный родитель или опекун, которые также должны быть российскими гражданами. Выплаты несовершеннолетним детям начали производиться с 1 июня 2020 года. Практикой отмечены случаи, когда недопропорядочные отцы, проживающие отдельно от детей, регистрировались на сайте Госуслуги и получали выплату. Естественно при этом несовершеннолетные дети оставались без положенных им пособий. Эта ситуация требует разрешения. С одной стороны, сохранить доступность выплат, с другой, защитить их от недобросовестных получателей.

- выплата 5000 рублей на детей до 3 лет в течение трех месяцев (апрель, май, июнь) первой волны пандемии коронавируса 2020 года. Как и предыдущая, выплата призвана оказать поддержку семьям с детьми из-за экономических проблем, вызванных сложной эпидемиологической ситуацией. В этом случае родители и дети должны быть гражданами Российской Федерации и доход семьи не имеет значения.

Помимо вышеупомянутых выплат, непосредственно связанных с распространением коронавирусной инфекции, семьи с детьми получили пособие на детей от 3 до 7 лет введенное в начале 2020 года по инициативе главы государства раньше установленного срока - в июне, вместо июля 2020 года. Это пособие, было предназначено главным образом, для компенсации бедности, т.к. выплачивается если доходы на каждого члена семьи не превышают прожиточный минимум. Но, многие семьи, которые сами считают себя малоимущими, не приобрели право на выплату, т.к. превысили учитываемые доходы, а другие, имеющие теневые доходы, неофициальный заработок, дорогие автомобили пособие смогли получить. Также необходимо учесть, достаточное количество асоциальных семей, которые не работают не потому, что нет работы, а потому что не хотят работать. При этом имеют, как правило, много детей, и получают всевозможные пособия и компенсации. По нашему мнению, детское пособие следует начислять строго при трудозанятости родителей.

Кроме того, проведенная в России в июле 2020 года конституционная реформа своей приоритетной задачей ставила именно совершенствование конституционных норм в рамках реализации семейной политики государства. Органы власти с начала 2020 года повсеместно демонстрируют вовлеченность в деятельность по поддержке семей в России с момента принятия «первого демографического пакета» вплоть до послания Президента РФ Федеральному собранию от 15 января 2020 года и принятия «второго демографического пакета» [1].

На сегодняшний день для российского государства особое значение приобретает защита, в частности, уголовно-правовая охрана института материнства и детства, ценность которого подчеркнута отечественным законодателем в конституционно провозглашенных положениях (ст. 38 Конституции РФ), а также в ряде международно-правовых документах (например, в преамбуле Конвенции по правам ребенка). Это не является удивительным, ведь именно от обеспечения нормальной реализации материнской функции, благополучного детства зависит и все дальнейшее развитие личности отдельно взятого человека, а, следовательно, и социума, в целом.

Исходя из вышеизложенного, можем заключить, что семья, материнство, отцовство и детство выступают прерогативой современной социальной политики государства, которая состоит из факторов, направленных на дальнейшую перспективу становления, развития, взаимодействия поколений, а также государственной и народной преемственности, готовность нового поколения к осознанию своей ценности в развитии сегодняшнего общества, а также ценности прав, принадлежащих им с рождения, и гарантированных основным законом страны.

Кроме того, охрана материнства и детства является непосредственной обязанностью государства по созданию обеспечивающих условий, необходимых для рождения, выживания и защиты детей, их полноценного развития и выполнения семьей всех функций общества. Но не надо забывать, что ответственность за детей законодательно определена не только в отношении матери, но и отца.

Итак, государственная политика призывает на 
всех уровнях социального обеспечения действовать в интересах детей. Каждый ребенок имеет право расти в семье, где есть мама и папа. Но в жизни случается всякое. Если в результате несчастного случая или по какой-то иной причине родители не смогут заботиться о детях, государство обязуется взять на себя такую роль.

Поэтому институт семьи в современном обществе нуждается в поддержке и охране.

\section{ЛИТЕРАТУРА}

1. Конституция Российской Федерации (принята всенародным голосованием 12 декабря 1993 года) // Российская газета. №237 25 декабря 1993.

2. Семейный кодекс Российской Федерации от 29 декабря 1995 г. N 223-Ф3 // Собрание законодательства Российской Федерации от 1 января 1996 г. № 1 ст. 16

3. Автухова, 0.В. Актуальные проблемы социально-правовой защиты материнства и детства в современной России / 0.В. Автухова // Актуальные проблемы государства и общества в области обеспечения прав и свобод человека и гражданина. - 2020. - № 1. - С. 250-254.

4. Левицкий, Д. К вопросу о механизме социально-правовой защиты отцовства, материнства и детства в российской федерации / Д. Левицкий, С. Чернолихов, 0.Е. Анисимова // В сборнике: Экономика, управление и финансы в XXI веке: факты, тенденции, прогнозы. Материалы международной научно-практической конференции. 2020. - С. 399-40.

5. Федеральная служба государственной статистики // rosstat.gov.ru

6. Большая пресс-конференция президента РФ Владимира Путина 17 декабря 2020 //politics/2020-12-17/100_putinpress2020.html

( Кузнецова Наталья Александровна (kuz1503@уandex.ru), Матвеева Тамара Павловна (matveeva33@mail.ru).

Журнал «Современная наука: актуальные проблемы теории и практики»

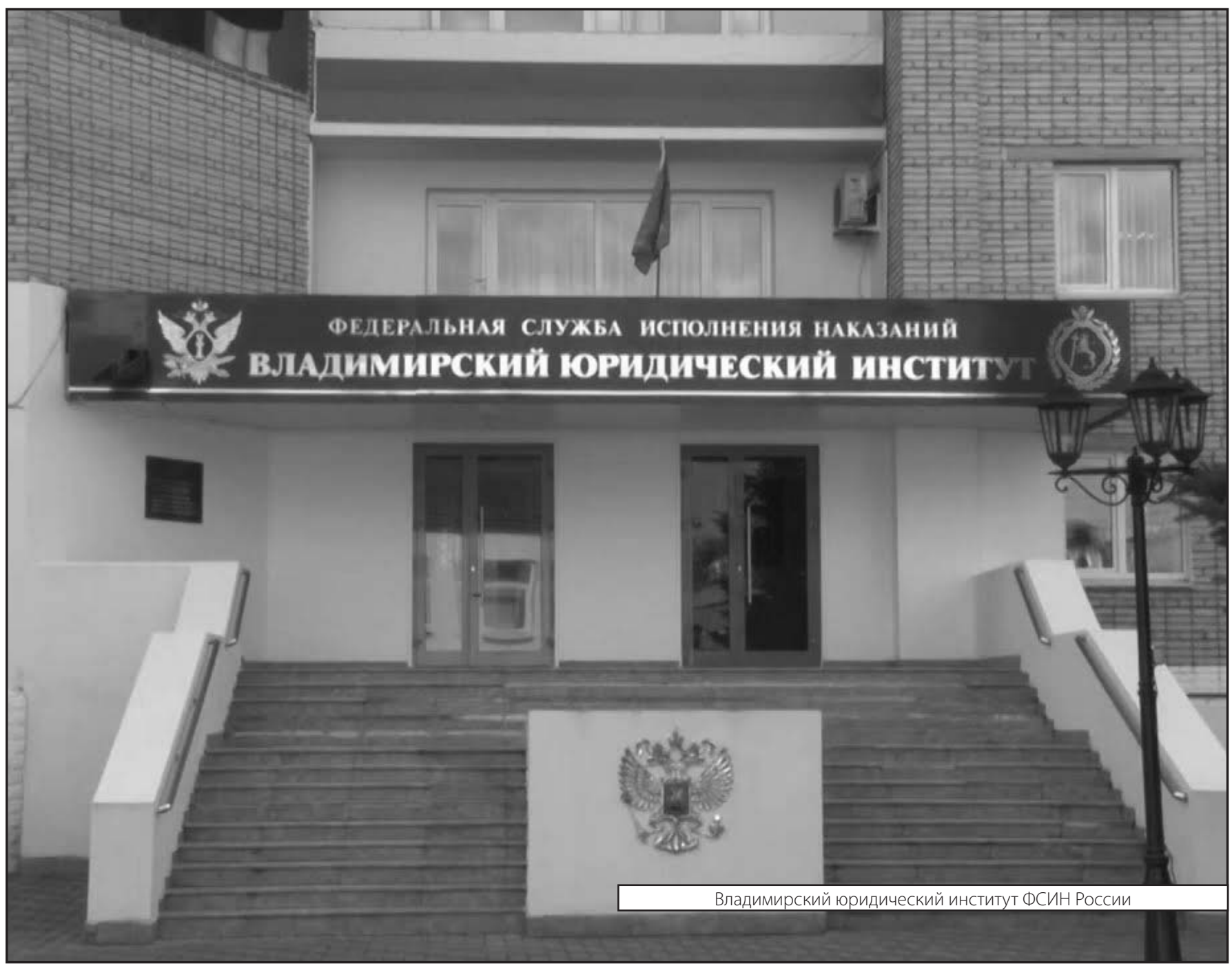

